\title{
Prevalence of some Enteric Bacterial Infections Causing Rabbit Enteritis and Attempts to Control Rabbit Coli Enteritis with Phytobiotics
}

\author{
Ahmed, K. Ismail ${ }^{1}$, Hanan, M.F. Abdien ${ }^{2 *}$, Dalia, M. Hamed ${ }^{2}$, and Wail M.K. El Feil ${ }^{2}$ \\ ${ }^{1}$ Diagnostic Veterinary Hospital, Hussania, Sharkia \\ ${ }^{2}$ Avian and Rabbit Medicine Department, Faculty of Veterinary Medicine, Suez Canal \\ University
}

\begin{abstract}
A field survey was conducted to monitor the prevalence of some enteric bacterial infections incriminated in rabbit enteritis outbreaks. Ninety bacterial isolates were recovered from diseased /or freshly dead rabbits with a history of severe diarrhea representing four farms in El-Sharkia Province. The predominant isolates were E. coli (24.29\%), Klebsiella (14\%), Proteus miriables (2.33\%) and Proteus vulgaris (1.4\%). All bacterial isolates were highly sensitive to levofloxacin. Isolated E. coli was later identified by using PCR. Fifty-three recently weaned White New Zealand rabbits were experimentally used to monitor the efficacy of two herbal extracts and probiotics (Healthy gut $\AA$; Immuplant plus $®$ ) supplementation with/or without enrofloxacin treatment in controlling artificial infection of the pathogenic streptomycin adapted E. coli isolate strain in a rate of $\left(2.5 \times 10^{10} \mathrm{CFU} / 0.1 \mathrm{~mL} /\right.$ rabbit orally $)$ and improvement of growth parameters. Our results showed that; treatment with two (Healthy gut ${ }^{\circledR}$; Immuplant plus $®$ ) induced an improvement in general health conditions and growth performance parameters with significant decrease in total labeled pathogenic E. coli shedding of infected supplemented group. In addition, this supplementation when followed by treatment with enrofloxacin after $E$. coli infection refluxed significant reduction of bacterial shedding with improvement of mean body weight and feed conversion ratio when compared with all other treated groups.
\end{abstract}

Keywords: Rabbit, E. coli, Diarrhea, Herbal.

\section{Introduction}

Rabbits play an important role in solving shortage in meat, as rabbit meat contains a high percentage of protein, low fat and palatable taste [1]. Weaning is transitory and stressful for rabbit in which beneficial cecal microflora is not yet established [2]. Young kids consume only mother's milk up to $18-20$ days then begin to eat solid feed gradually [3]. The fermentative capacity of caecum begins to develop [4]. Stress factors are the main predisposing factors of gastrointestinal diseases and particularly diarrhea are highly dominant problems during the weaning period of rabbits [5] including major commercial losses due to weight impairment, epizootic diarrhea, mortalities and veterinary costs [6]. Bacterial and parasitic (Eimeria spp.) agents can be selected as potential diarrhea inducers that cause severe economic losses in rabbit production [7]. E. coli is incriminated in the etiology of digestive disorders in rabbits and remains one of the main causes of economic losses [8]. It is a difficult problem due to resemblance with other digestive diseases with difficult differential diagnosis, treatment and also resistance developed to antibiotics [9]. Screening for bacterial agents causing mortalities in rabbits showed the isolation of enterobacteriacae organisms from about $42 \%$ of inspected cases and E. coli was the more prevalent isolated organism $24.29 \%$ [10]. The use of antibiotics and coccidiostats as feed additives for promoting growth has been banned by European Union (EU). New alternative replacements are searched [11]. Because of rabbits were susceptible to enteric diseases particularly after weaning, and use of antibiotics in treatment for long time could only lead to microbial resistances in farm animals. Therefore, there have been several alternatives such as herbal extracts, probiotics and organic acids [12]. Probiotics are sector from the beneficial flora which has positive effect in the prevention and control of specific pathologic disorders especially gastrointestinal disorders when applied orally. Probiotics that contain yeast, live bacteria or bacterial spores can reduce enteric diseases of rabbits [13]. Beneficial probiotics provided a barrier, which reduced the response of the host epithelium to pathogenic infections. Lactic acid-producing 
bacteria produce some acid materials which direct the intestinal $\mathrm{pH}$ toward acidity so decrease the viability and the virulence properties of pathogenic E. coli O157: where it competes with $E$. coli on adhesion of some receptors as fimbriae- receptor on epithelial cells surface; so, reduce binding sites available for enteric pathogens [14]. Herbal extract or essential oils have an inhibitory effect against different pathogenic bacteria, its effectiveness and values depend on the types of herbal, means of extraction, concentration, mixture with other different elements such as, sandalwood and vetiver oils [15]. Aromatic plants are an important source of natural flora and represented an essential resource in many fields [16].

This work was carried out for isolation and identification of the probable bacterial agents causing diarrhea in rabbits and attempts for using herbal and probiotic extracts (Healthy gut ${ }^{\circledR}$; Immuplant plus $\left.{ }^{\circledR}\right)$ with /or without enrofloxacin treatment as a prophylaxis and control of pathogenic $E$. coli infection in recently weaned rabbits

\section{Material and Methods}

\section{Examined rabbits}

Two hundred fourteen rabbits aged between 1-10 weeks old (168 life and 46 freshly dead) of different breeds with a history of mortalities and severe diarrhea were clinically examined and subjected to post mortem examination [17].

\section{Necropsy and sampling}

One hundred eighty-six rectal swabs from life as well as 46 specimens from freshly dead (liver, small intestine, cecum, stomach, heart and lungs) samples were collected aseptically and submitted for bacteriological investigation.

\section{Bacteriological examination}

Rectal swabs \& Loopfuls from internal organs were investigated for the occurrence of enterobacteriacae were directly cultivated aerobically into Nutrient broth and Rappaport broth, then incubated at $37{ }^{\circ} \mathrm{C}$ and $42{ }^{\circ} \mathrm{C}$ for 24 hours, followed by sub-culturing on differential media as MacConkey agar, Eosin-methylene blue (EMB) agar, Xylose - lysine - deoxycholate (XLD) agar, and Nutrient agar. Agar plates were incubated at $37{ }^{\circ} \mathrm{C}$ and $42^{\circ} \mathrm{C}$ for 24 hours. Colonies with characteristic growth for any bacteria were sub-cultured two successive times for pure culture then picked up for further phenotypical and biochemical identification using Gram stain and standard biochemical tests [17].

\section{Antibiotic sensitivity test}

All bacterial isolates were subjected to disc diffusion method using available commercial antibiotic discs (Oxoid Laboratory, Oxoid, Unipath Ltd, Basingstoke) according to the procedures given by the National Committee for Clinical Laboratory Standards [18] then incubated for 24 hours at $37^{\circ} \mathrm{C}$. Interpretation of the inhibition zone given by manufacturer was used to interpret isolates into sensitive or intermediate or resistant groups.

\section{Parasitological examination}

Smears of gastrointestinal tract of freshly dead rabbits were taken to detect the presence of helminthes and $E$. oocysts.

\section{Molecular characterization of pathogenic $E$. coli by PCR assay.}

Ten E. coli isolates of this study were chosen and submitted to molecular identification. PCR was carried out at the biotechnology unite Animal health research institute, Dokki, Giza, Egypt. DNA extraction was done according to QIAamp DNA mini kit instructions. Preparation of PCR Master Mix was performed according to Emerald Amp GT PCR master mix (Takara) Code No. RR310A. Visualization of PCR products was completed by using agarose gel electrophoresis [19] The primers used for characterization of pathogenic $E$. coli in reverse transcription polymerase chain reaction targeted $e a e A$ gene (248 bp) was forward F: ATG CTT AGT GCT GGT TTA GG, R: GCC TTC ATC ATT TCG CTT TC [20] and F: TGC AGA ACG GAT AAG CCG TGG, R: GCA GTC ACC TGC CCT CCG GTA [21] for FimH gene (508 bp) detection.

\section{Experimental rabbits}

Fifty-three recently weaned White New Zealand rabbits aged 30-35 days old obtained from private farm in San El- Hager were experimentally used. All rabbits were housed in cleaned disinfected metal cages with slant 
floor (3rabbits/cage) at room temperature (20$22{ }^{\circ} \mathrm{C}$ ) and fed pelleted commercial antibiotic and anticoccidial free diet.

\section{Streptomycin $E$ coli resistant strain (challenge strain)}

Isolated field strains of $E$. coli were labeled streptomycin resistant [22]. This method was used to facilitate bacterial counts and reisolation of the challenge strain from experimentally infected rabbits on specific media containing streptomycin.

\section{Herbal extracts and probiotics}

Two Herbal extracts and probiotics (Healthy gut ${ }^{\circledR}$; Immuplant plus ${ }^{\circledR}$ ) (Animalia pharm, Egypt) were used according to manufacture instructors. Healthy gut ${ }^{\circledR}$ contains enzymes as (protease, amylase, lipase...), probiotics (special strains of Enterococcus and bacillus species...), Mannan oligo saccharide (M.O.S), Glucan, and organic acids as (Propionic, acetic, formic acids), sodium butyrate, copper oxin and other herbal extracts. Immuplant plus $₫$ contains vitamin $E$, M.O.S, B- Glucan, zinc, lysine, methionine, selenium, iron, chromium and 8 specific herbal extracts. They are intended for stimulation of salivation, increased forage consumption, improved utilization of carbohydrates and proteins and stabilization of the resident intestinal microflora.

\section{Experimental design}

Fifty-three recently weaned White New Zealand rabbits were experimentally used. Five rabbits were randomly chosen and subjected for postmortem and bacterial isolation on media containing streptomycin to be sure its freedom from pathogenic E. coli. The rest of 48 rabbits were divided into 6 equal groups ( 8 for each group). G1: nontreated - non infected (negative control). Groups (2, 4, 5): rabbits were received (Healthy gut $\AA$; Immuplant plus $\AA$ ) in drinking water from the first day of the experiment till day $18^{\text {th }}$ in a rate of $1 / 2 \mathrm{ml}$ of each /liter water. Groups $(3,4,5,6)$ : rabbits were infected orally with pathogenic streptomycin adapted $E$. coli strain $\left(2.5 \times 10^{10} \mathrm{CFU} / 1 \mathrm{ml} / \mathrm{rabbit}\right)$ at day $7^{\text {th }}$ of experiment after supplementation. Groups (3,
4): rabbits were injected intramuscularly with Enrofloxacin (1/2 ml/each rabbit of diluted Enrofloxacin $1 \mathrm{ml}: 10$ D.W) started from $3^{\text {rd }}$ day post infection for 5 successive days. Group 6: rabbits were kept as infected - non-treated (positive control).

\section{Collected parameters}

Mean body weights (MBW), feed intake (FI) and feed conversion ratio (FCR) were calculated weekly till the end of the experiment [23]. Clinical signs, morbidity and mortality were recorded daily. All dead rabbits were clinically, pathologically and bacteriologically examined. Three rabbits were randomly collected from each group and slaughtered at days $3^{\text {rd }}$ and $10^{\text {th }}$ post infection for monitoring total shedding of labeled pathogenic $E$. coli counts, lesions scoring of $E$. coli experimentally infected groups and reisolation of labeled challenge E. coli strain. As well as, fecal samples and rectal swabs were collected at day $6^{\text {th }}$ post infections to monitor the $E$ coli shedding by detecting total pathogenic E. coli counts.

\section{Statistical analysis}

Data of the present study were analyzed using One-way Analysis of Variance (ANOVA) procedures [24] for testing of significance among the studied groups. Means separation and pair wise comparisons were done by Duncan's Multiple Range test [25]. Statistical analyses were conducted by SPSS for windows [26]. Results are considered significant at probability level of 0.05 for each $(\mathrm{P} \leq 0.05)$.

\section{Results}

Clinically examined rabbit flocks showed symptoms such as anorexia, loss of body weight, soiled perineal region with watery feces and some showed gelatinous mucus with loss fur of hind legs. Some rabbits exhibited impaction or tympani, soft pellets on the cages, emaciation and dehydration with mortalities especially in young ages at $4-7 \mathrm{wks}$ old. Post mortem examination revealed signs of septicemia with distended small intestine with gases or foamy contents and cecum loaded with gases and hard contents. 
Table 1: Prevalence of $E$. coli and $E$. oocysts infection isolated from examined rabbit flocks in relation to age.

\begin{tabular}{|c|c|c|c|c|c|c|c|c|}
\hline \multirow[t]{2}{*}{$\begin{array}{l}\text { Farms } \\
\text { locality }\end{array}$} & \multirow[t]{2}{*}{$\begin{array}{l}\text { flock } \\
\text { capacity }\end{array}$} & \multirow[t]{2}{*}{$\begin{array}{l}\text { Age of } \\
\text { rabbits }\end{array}$} & \multirow{2}{*}{$\begin{array}{c}\text { Morbidity } \\
\%\end{array}$} & \multirow{2}{*}{$\begin{array}{c}\text { Mortality } \\
\%\end{array}$} & \multicolumn{2}{|c|}{ No. of positive $E$ coli } & \multicolumn{2}{|c|}{$\begin{array}{l}\text { No. of positive } \\
\text { Eimeria spp. }\end{array}$} \\
\hline & & & & & No. & $\%$ & No. & $\%$ \\
\hline San El & 1300 & $1-3 \mathrm{~W}$ & 5 & 3.2 & $5 / 22$ & 22.7 & $0 / 46$ & 0 \\
\hline \multirow[t]{2}{*}{ Hagar (A) } & & $4-7 \mathrm{~W}$ & 22.5 & 7.6 & $11 / 22$ & 50 & & \\
\hline & & $8-10 \mathrm{~W}$ & 6.5 & 4.16 & $6 / 22$ & 27.2 & & \\
\hline San El & 900 & $1-3 \mathrm{~W}$ & 6.6 & 2.5 & $4 / 18$ & 26.6 & $0 / 9$ & 0 \\
\hline \multirow[t]{2}{*}{ Hagar-(B) } & & $4-7 \mathrm{~W}$ & 18.2 & 7.1 & $9 / 18$ & 50 & $5 / 9$ & 55.5 \\
\hline & & $8-10 \mathrm{~W}$ & 6.2 & 4.9 & $5 / 18$ & 27.7 & $4 / 9$ & 44.4 \\
\hline Menia-El- & 450 & $1-3 \mathrm{~W}$ & 4 & 3.5 & $0 / 8$ & 0 & $0 / 6$ & 0 \\
\hline \multirow[t]{2}{*}{ Kamh } & & $4-7 \mathrm{~W}$ & 15 & 5 & $4 / 8$ & 50 & $5 / 6$ & 83.3 \\
\hline & & $8-10 \mathrm{~W}$ & 11 & 2.7 & $4 / 8$ & 50 & $1 / 6$ & 16.6 \\
\hline San El & 320 & $1-3 \mathrm{~W}$ & 8.2 & 4.3 & $2 / 4$ & 50 & $0 / 4$ & 0 \\
\hline Hagar & & $4-7 \mathrm{~W}$ & 21.3 & 10.1 & $2 / 4$ & 50 & $3 / 4$ & 75 \\
\hline (El-Qasabi) & & $8-10 \mathrm{~W}$ & 9.5 & 4.6 & $0 / 4$ & 0 & $1 / 4$ & 25 \\
\hline Total & 2970 & & & & 52 & & 19 & \\
\hline
\end{tabular}

No.: number of isolates/ Total isolated number of each flock

N.B: All positive $E$. oocysts were detected in intestine only.

Bacterial isolation and biochemical identification revealed recovery of 90/214 with a percentage of $(42 \%)$ total bacterial isolates from examined samples in which the predominant one was E. coli spp. (24.29\%) followed by Klebsiella pneumoniae (14\%) then Proteus mirabilis (2.33\%) and Proteus vulgaris $(1.4 \%)$. The high rate of $E$. coli recovery was from intestine $14 / 52(26.92 \%)$ followed by liver $11 / 52(21.15 \%)$. Table (1) showed the isolation rate of $E$. coli and $E$. oocysts in relation to age which showed the highest isolation rate by $50 \%(26 / 52)$ of total isolated $E$. coli all over the survey at age period (4-7wks).

All isolates were highly sensitive to Levofloxacine, Ofloxacin (90-100\%), chloramphenicole (80-100\%) followed by Doxycycline (70-90\%). While intermediate sensitivity was recorded with Neomycin, Erythromycin (40-70\%) and low sensitivity was obtained with Amoxicillin (20-50\%), at the same time all isolates were resistant to Bacitracin. Parasitological examination revealed detection of intestinal $E$. oocyst only in19/46 of freshly dead examined cases.

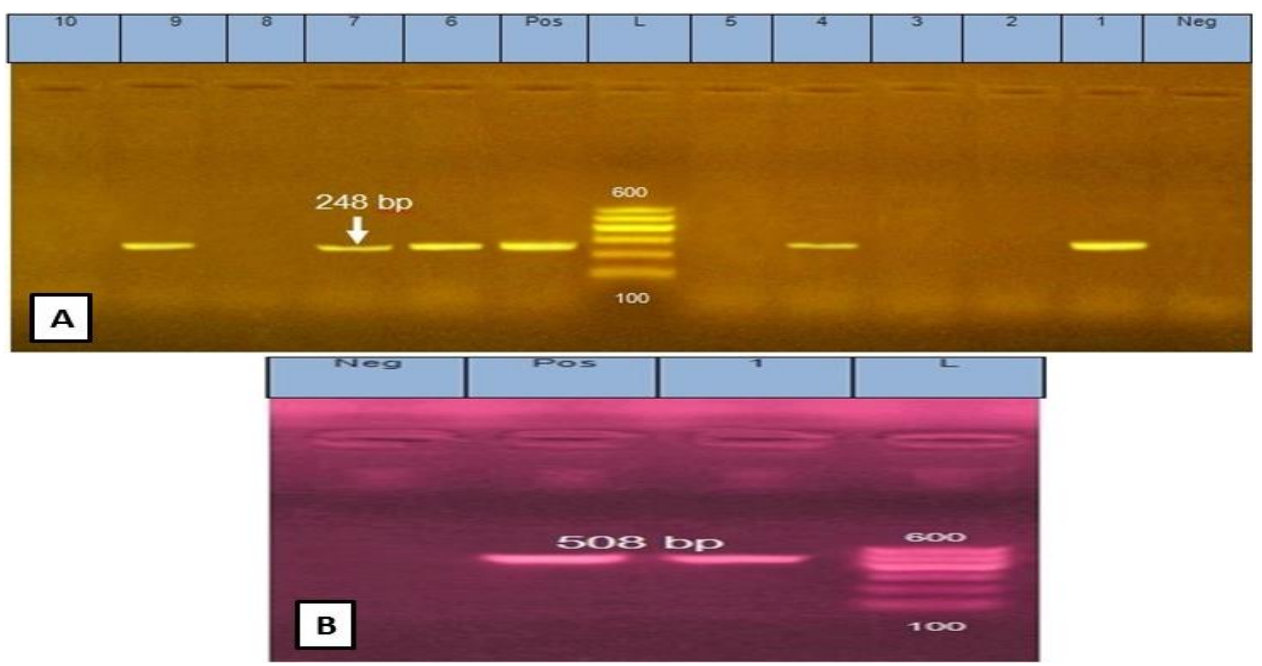

Figure 1: Results of molecular identification of $E$. coli by detection of (eaeA gene \& fim $\mathrm{H}$ gene) characteristic genes for pathogenic $E$. coli at specific 248 pb and 508 pb respectively using PCR. A: Lanes 1-10: samples (1, 4, 6, 7 and 9); Pos: Positive control; Neg.: Negative control; L: [Gel pilot100 bp ladder (Qiagen, 100-600 bp); positive amplification of specific $e a e A$ gene in five samples with band at 248 bp. B: Lane 1: sample; Pos: Positive control; Neg.: Negative control; L [Gelpilot100 bp ladder (Qiagen, 100-600 bp)] Positive amplification of specific band at $\sim 508$ bp of the fim $\mathrm{H}$ gene in one sample. 
Figure (1) illustrates positive amplification of specific eaeA gene in five samples with band at $\sim 248 \mathrm{bp}$. All 5 positive samples were pooled for detection of fim $\mathrm{H}$ gene with amplification band at $508 \mathrm{pb}$ which were characteristic for pathogenic E. coli.

Clinical signs of experimentally examined rabbits showed signs of respiratory manifestations and diarrhea, meanwhile, severe enteritis with ballooned small intestine, peritonitis and enlarged cecum were detected. The signs were clearly recorded in rabbit of positive control G 6 (infected nonsupplemented -non-treated) followed by Healthy gut ${ }^{\circledR} ;$ Immuplant plus ${ }^{\circledR}$ supplemented -infected G 5. The lowest signs observed in G4 (Healthy gut $\AA$; Immuplant plus ${ }^{\circledR}$ supplemented enrofloxacin treated).

Results concerning the body performance data of the experimental groups were presented in
Table 2 \& 3. Group 2 (Healthy gut@; Immuplant plus@ supplemented, non infectednon treated) showed significant higher performance ratio when compared with other groups, followed by Group 4 (Healthy gut@; Immuplant plus ${ }^{\circledR}$ supplemented enrofloxacin treated) then (enrofloxacin treated) Group 3.

Results related to total bacterial count and comparative clinical data (morbidity; mortality; lesion score) of the experimentally infected groups revealed that, Group 6 (infected control) at $3^{\text {rd }}$ day of infection recorded highest $E$. coli shedding counts compared to other groups as well as highest morbidity and lesion score $(75 \%$ and 0.75$)$ respectively. In contrast, Group 4 (supplemented enrofloxacin treated) showed lowest E. coli count, morbidity and lesion score than Group 3 (enrofloxacin treated), and Group 5 (supplemented) (Table 4).

Table 2: Influence of Healthy gut ${ }^{\circledR}$; Immuplant plus® supplementation/or Enrofloxacin treatment on mean body weight (MBW)

\begin{tabular}{|c|c|c|c|c|c|}
\hline \multirow{2}{*}{$\begin{array}{c}\text { Group } \\
(\text { Mean } \pm \text { S.E. })\end{array}$} & \multicolumn{4}{|c|}{ Days (mean \pm S.E.) } & \multirow{2}{*}{ Total } \\
\hline & 0 day & $4^{\text {th }}$ & $11^{\text {th }}$ & $18^{\text {th }}$ & \\
\hline Gr & $538.5^{i} \pm 26.17$ & $604.14^{\text {ghi }} \pm 30.5$ & $814.83^{\text {cdefg }} \pm 40.14$ & $1006.7^{\text {abcd }} \pm 82.8$ & $685.25^{\mathrm{a}} \pm 37.97$ \\
\hline Grol & $570.25^{i} \pm 50.67$ & $659.14^{\text {fghi }} \pm 41.76$ & $909.86^{\text {bcd }} \pm 53.24$ & $1128.33^{\mathrm{a}} \pm 82.11$ & $757.2^{\mathrm{a}} \pm 46.56$ \\
\hline Group3 & $610.75^{\text {ghi }} \pm 44.33$ & $655.38^{\text {bcd }} \pm 42.52$ & $831.38^{\text {cdef }} \pm 41.7$ & $1020.6^{\mathbf{a b c}} \pm 61.27$ & $754.59^{\mathrm{a}} \pm 35.58$ \\
\hline Group4 & $595.25^{\text {hi }} \pm 62.08$ & $650.63^{\text {fghi }} \pm 61.44$ & $897.63^{\text {bcd }} \pm 65.19$ & $1042.8^{\mathbf{a b}} \pm 65.23$ & $766.14^{\mathrm{a}} \pm 44.04$ \\
\hline Group5 & $582.63^{\mathrm{i}} \pm 48.57$ & $674.29^{\text {fghi }} \pm 55.65$ & $876.29^{\text {bcde }} \pm 37.38$ & $898.4^{\text {bcd }} \pm 25.56$ & $741^{\mathrm{a}} \pm 51.07$ \\
\hline Group6 & $618.25^{\mathrm{ghi}} \pm 41.56$ & $668^{\text {fghi }} \pm 37.03$ & $832^{\text {cdef }} \pm 43.5$ & $801.17^{\text {defgh }} \pm 166.48$ & $725.1^{\mathrm{a}} \pm 39.45$ \\
\hline Total & $585.94^{c} \pm 18.49$ & $652.33^{c} \pm 18.18$ & $857.64^{b} \pm 19.46$ & $963.74^{\mathrm{a}} \pm 58.65$ & $739.25 \pm 17.29$ \\
\hline
\end{tabular}

Group 1: Negative control. Group 2: Supplemented control. Group 3: Infected enrofloxacin treated. Group 4: Supplemented enrofloxacin treated infected. Group 5: Supplemented infected. Group 6: Infected control. Means carrying different superscripts are significantly different at $(\mathrm{p}<0.05)$.

Results related to comparative clinical data (morbidity; mortality; lesion score) of experimentally infected groups showed that highest morbidity and lesion score recorded in G6 were $75 \%$ and 0.75 respectively while lowest morbidity (37.5\%) and lesion score (0.37) was successfully registered in Group 4 (Table 4).

Re-isolation trails of challenge labeled $E$. coli was successfully done in all days of necropsy of all infected groups with different degree, while can't be re-isolated from both negative non-infected control (Groups 1 and 2).

\section{Discussion}

In this study, particular attention was directed for isolation and identification of some bacterial agents causing diarrhea in rabbit. Bacterial and parasitic especially Eimeria spp. are incriminated in the etiology of diarrhea that causes severe economic losses in rabbit production [7]. Clinically field examined rabbits showed signs like anorexia, loss of body weight, tympani and diarrhea. These findings agreed with those of Licois 
[27]. Post mortem examination revealed signs of septicemia in rabbit's examined, with distended small intestine with gases /or foamy contents and cecum loaded with gases as mentioned formerly [28]. The etiological agents' identification showed presence of 19/46 Eimeria infection with percentage 41.3\% from examined rabbits aged 4-7 weeks while no occurrence was detected in rabbits aged 1-3 weeks old. Records of bacterial isolation showed 90/214 (42\%) positive bacterial isolates in which the predominant isolates were E. coli $24.29 \%$, Klebsiella pneumoniae $14 \%$ then $P$. mirabilis $2.33 \%$ and Proteus vulgaris 1.4\%. Age period (4-7wks) showed highest isolation rate of pathogenic $E$. coli by $50 \%(26 / 52)$ of total isolated $E$. coli all over the survey with higher detection rate of intestinal oocysts $68.4 \%(6 / 9)$ at the same age side by side which may be contributed to the role of coccidoial infection as a predisposing factor for colibacillosis infection in rabbits. Moreover; the weaning stress at 4-6 wks age which associated with change in ration types $\&$ consistency which may reflect on the health condition of the GIT disorders, which may get need to use some probiotics, herbal extracts and prophylactic medication at the weaning period to maintain the healthy condition of the GIT and avoid such problems.

Table 3: Influence of Healthy gut ${ }^{\circ}$; Immuplant plus® supplementation/or Enrofloxacin treated on growth performance parameters.

\begin{tabular}{lccc}
\hline Groups & Mean feed intake (FI) & Mean weight gain (WG) & Feed conversion ratio (FCR) \\
\hline Group1 & $312.98^{\mathrm{a}} \pm 55.35$ & $167.54^{\mathrm{a}} \pm 50.73$ & $1.82^{\mathrm{ab}} \pm 0.07$ \\
Group2 & $322.5^{\mathrm{a}} \pm 100.2$ & $188.46^{\mathrm{a}} \pm 55.35$ & $1.74^{\mathrm{b}} \pm 0.09$ \\
Group3 & $291.83^{\mathrm{a}} \pm 99.92^{\mathrm{cd}}$ & $136.62^{\mathrm{bc}} \pm 45.5$ & $2.07^{\mathrm{a}} \pm 0.11$ \\
Group4 & $315.42^{\mathrm{a}} \pm 104.02$ & $159.77^{\mathrm{bcd}} \pm 55.44$ & $2.02^{\mathrm{ab}} \pm 0.07$ \\
Group5 & $294.58^{\mathrm{a}} \pm 95.7$ & $144.87^{\mathrm{a}} \pm 49.75$ & $2.09^{\mathrm{a}} \pm 0.09$ \\
Group6 & $273.75^{\mathrm{a}} \pm 81.39$ & $132.38^{\mathrm{d}} \pm 41.42$ & $2.1^{\mathrm{a}} \pm 0.08$ \\
\hline
\end{tabular}

Group 1: Negative control. Group 2: Supplemented control. Group 3: Infected enrofloxacin treated. Group 4: Supplemented enrofloxacin treated infected. Group 5: Supplemented infected. Group 6: Infected control. Means carrying different superscripts are significantly different at $(\mathrm{p}<0.05)$.

The obtained results matched with Hassan et al. [29] who reported, the bacteriological examination of a total 150 rabbits (100 dead, 30 diseased and 20 apparently healthy) were obtained from private farms in Sharkia province showed $97(64.71 \%)$ positive bacterial where the predominant isolates were E. coli $26(26.81 \%)$ and P. multocida $19.52 \%$. Similar results were obtained previously by Sabry and Mohamed [30] who isolated $40 \mathrm{E}$. coli isolates from 48 fecal samples from diarrheic rabbits. Whereas Greenham [31] recorded that enteropathogenic E. coli constitute one of the main infectious agents in diarrheic rabbits and are responsible for 10$60 \%$ of the losses. Our results in agreement with Shahin [8] who examined 225 specimens represented 45 rabbits; either freshly dead or sacrificed suffered from mucoid enteropathy syndrome which revealed isolation of $38 \mathrm{E}$. coli; 25 Klebsiella spp. and 23 Citrobacter spp.". Similar results obtained by Sumitha and Sukumar [32] who described an outbreak of Klebsiella pneumoniae associated with septicemia, enteritis and severe respiratory distress in rabbit farms with $20 \%$ mortality in total 1200 rabbits. Our results disagree with Martino and Luzi [33] who recorded the presence of Pseudomonas aeruginosa (5/32) and Klebsiella pneumoniae (3/32) from 32 samples collected from different rabbits with enteritis. 
Table 4: Comparative clinical data and total labeled $E$. coli shedding among different experimentally infected groups.

\begin{tabular}{cccccccccc}
\hline $\begin{array}{c}\text { Collected Morbidity } \\
\text { parameters }\end{array}$ & \multicolumn{9}{c}{ Lesion score } \\
& & $(-)$ & $(+)$ & $(++)$ & $(+++)$ & Score & $\mathbf{3}^{\text {rd }}$ & $\mathbf{6}^{\text {th }}$ & $\mathbf{1 0}^{\text {th }}$ \\
\hline Group1 & 0 & 0 & 0 & 0 & 0 & 0 & 0 & 0 & 0 \\
Group2 & 0 & 0 & 0 & 0 & 0 & 0 & 0 & 0 & 0 \\
Group3 & 50 & 2 & 1 & 2 & 1 & 0.5 & $183^{\mathrm{b}} \pm 60$ & $70^{\mathrm{b}} \pm 4$ & $0.5^{\mathrm{b}} \pm 0.16$ \\
Group4 & 37.5 & 3 & 2 & 1 & - & 0.37 & $3.16^{\mathrm{b}} \pm 1.27$ & $0.16^{\mathrm{a}} \pm 0.46$ & $0.0012^{\mathrm{a}} \pm 0.001$ \\
Group5 & 50 & 2 & 1 & 2 & 1 & 0.5 & $2.1^{\mathrm{b}} \pm 0.64$ & $0.36^{\mathrm{b}} \pm 0.18$ & $0.014^{\mathrm{b}} \pm 0.026$ \\
Group6 & 75 & - & 2 & 2 & 2 & 0.75 & $200^{\mathrm{b}} \pm 100$ & $150^{\mathrm{b}} \pm 12$ & $66^{\mathrm{b}} \pm 14$ \\
\hline
\end{tabular}

(-) No lesions N.B: At $3^{\text {rd }} \& 10^{\text {th }}$ necropsy 3 rabbits/group; At $6^{\text {th }} /$ rectal swabs $\&$ feceas only

(+) Mild gastroenteritis with soft feces, visible perineal staining and no signs of dehydration

$(++)$ Moderate gastroenteritis with soft to pulpous feces without mucous or stained perineal area and moderate degree of dehydration.

$(+++)$ Sever gastroenteritis with pulpous, semisolid to aqous diarrheic feces staining perineal area, tail and hind quarters with excessive degree of dehydration.

Lesion score $=$ Total lesion score $/$ Total number of rabbits per group

No mortalities were recorded ;

Means carrying different superscripts are significantly different at $(\mathrm{p}<0.05)$.

PCR results for the presence of E. coli eaeA gene and fim $\mathrm{H}$ gene showing positive specific amplification at $248 \mathrm{bp}$ and $508 \mathrm{bp}$ respectively, where such genes associated with pathogenic E. coli in most isolates. Similar results obtained by Karch et al. [34]. Detection of both genes can be added value in detection and differentiate pathogenic $E$. coli from non pathogenic one [35].

Most bacterial isolates revealed high sensitivity to Levofloxacin which agree with data obtained by Swennes et al. [36].

Regarding to body performance measures under this trail circumstances (feed intake, weight gain, food conversion rate and mean body weight) as shown in group2 supplemented with (Healthy gut@; Immuplant plus ${ }^{\circledR}$, non infected - non treated) showed significant higher performance ratio when compared with other groups, followed by group 4 (Healthy gut $\AA$; Immuplant plus $\AA$ supplemented enrofloxacin treated). This finding may be contributed to the presence of (betaine) which maintains the GIT and viable erected intestinal villi which increased the absorption surface in turn maximize utilization of feed intake. Moreover, probiotics compete with pathogenic bacteria in GIT epithelium cell receptor like fimbrae-I receptor GIT maintain healthy intact intestinal mucosa in turn increase the absorption surface [11]. Similar results observed by Kritas and Morrison [37] who recorded greatly improvement of growth parameters, MBW, WG and FCR in probiotics treated rabbits compared to the untreated groups.

Regarding to morbidity, mortality and lesion score in the experimental trail as shown in. Our results revealed that group 6 (infected control) showed highest morbidity rate $(75 \%)$ and lesion score (0.75) than other infected groups which confirmed the pathogenicity of the isolated $E$. coli strain. These findings attributed to over growth of E. coli in group 6 . While (Healthy gut ${ }^{\circledR}$; Immuplant plus ${ }^{\circledR}$ supplemented treated with enrofloxacin) group 4 showed the lowest morbidity rate $(37.5 \%)$ with lowest lesion score $(0.37)$ followed by group 3 (enrofloxacin treated) and group 5 (Healthy gut@; Immuplant plus ${ }^{\circledR}$ supplemented) which showed both morbidity $50 \%$ while G5 perform better lesion score over enrofloxacin treated G3. Similar results obtained by Bovera et al. [38] who recorded that mortality rate was equal to zero during the first week of the trial for all the groups after addition of mannan oligosaccharide for weaned rabbits suffered from Epizootic Rabbit Enteropath. Nearly, similar results were obtained by Petrov et al. [5]. In experimental infection with $E$. coli U83/39 (O15: H-) 
strains, observed appearance of diarrhea after 4 to 9 days following oral infection. Also, El Dimerdash [39] studied the effect of the probiotic supplementation in drinking water in recently weaned White New Zealand rabbits and recorded that mortalities were $(7 \%)$ in both infected groups, while morbidity showed great difference between them as probiotic infected group was milder than infected group. Most important potential pathogens such as $E$. coli were observed to be decreased in rabbits after herbals and probiotic supplementation. It can be attributed to that enteric commensally bacteria predominate over pathogenic bacteria. Moreover, probiotics known to have an inhibitory effect on $E$. coli in the intestinal tract of rabbit (40). Similar attempts to reduce basic microbial counts with addition of herbal extract and probiotics obtained by Panda et al. [41].

The results of total labeled pathogenic $E$. coli counts revealed that, group 4 (Healthy gut ${ }^{\circledR}$; Immuplant plus ${ }^{\circledR}$ supplemented and enrofloxacin treated) showed significant lowest shedding rate at $10^{\text {th }}$ day PI, followed by group 5 supplemented infected only with (Healthy gut ${ }^{\circledR} ;$ Immuplant plus $\left.{ }^{\circledR}\right)$ then group 3 (infected enrofloxacin treated). At days $3^{\text {rd }}$, $6^{\text {th }}$ and $10^{\text {th }} \mathrm{PI}$, there is no significant difference between group 4 and group 5 while both groups showed significant reduction in $E$. coli counts compared with group 3 and group 6. Also group 3 (enrofloxacin treated) showed significant reduction in $E$. coli counts over infected non treated positive control at $6^{\text {th }}$ and $10^{\text {th }}$.

\section{Conclusions}

Obtained results showed that; Diarrhea associated with enteritis is considered such critical economic and health hazard issue in rabbit farms with a high prevalence and mortality rate reach around $20 \%$. Weaning age is transitory and stressful period for rabbit and may associated with pathogenic bacteria overgrowth along the intestinal tract. Early weaning of young rabbits increased incidence of diarrhea and decrease growth rate with body weight. Eimeria infection favors proliferation of pathogenic E. coli. Our data pointed out the advantage of supplementation both (Healthy gut $\AA$; Immuplant plus $\left.{ }^{\circledR}\right)$ daily in drinking water at weaning period revealed increased growth performance parameters with significance decrease in total pathogenic labeled E.coli counts of infected groups and usage of Healthy gut ${ }^{\circledR}$; and Immuplant plus ${ }^{\circledR}$ or other preparation contain similar ingredients can improve the weight gain especially in rabbits with coli enteritis and can maintain the health of the rabbits' Gastrointestinal tract.

\section{Conflict of interest}

The authors have no conflict of interest to declare.

\section{References}

[1] Rashwan A.A, and Marai I.F.M (2000): Mortality in young rabbits Review.AWorld rabbit Science, 8 (3),111-124

[2] Kritas S.K. Petridou E. Fortomaris P., Tzika E., Arsenos G, and Koptopoulos G. (2008): Effect of inclusion of probiotics on microorganisms' content health and performance of fattening rabbits: Study in a commercial farm with intermediate health status.9 th World Rabbit Congress June 10-13, 2008 - Verona- Italy

[3] Gidenn, and Francoi Lebas (2002): Role of dietary fiber in rabbit nutrition and in digestive troubles prevention.2d Rabbit congress of the Americas,Habana City,Cuba, june19-22

[4] Padilha MT, Licois D,GidenneT, Carre, and Fonty G (1995): Relationship between microflora and caecal fermentation in rabbits before and after weaning. Reprod Nutr Dev. 1995; 35(4):375-386.

[5] Petrov, V.; Lyutskanov, M.; Vachkov, A.; Tsachev, I.; Mihaylov, G.; and Tanchev, S. (2005): Experimental E. coli (EPEC) infection in rabbits clinical and epidemiological studies and attempt to control with a phytobiotic. (Trakia Jthe obtainednal of Sciences, 3: 50-55.

[6] Milon, A. (1996): Weaned rabbit colibacillosis: a model for study of enteropathogenic Escherichia coli. Sixth World rabbit congress, Toulouse. 3: 13-22

[7] Okerman L., (1987): Pre-weaning mortality in rabbit's study of pathology and bacteriology. Land bouwtig dsch- rift.40 (5)1295-1304 
[8] Shahin, A.M.; Lebdah, M.A. and Ali, G.R.M. (2011): Escherichia Coli as an Etiological Agent of Mucoid Enteropathy in Rabbits. Researcher 2011; 3(7):8-16]. (ISSN: 1553-9865).

[9] Calhoa I. Pinheiro V., Monteiro J.M., and Coelho A.C. (2012): Cross sectional study of colibacillosis in portuguese rabbit farms. World Rabbit Science Association Proceedings 10 th World Rabbit Congress - September 3 - 6, 2012- Sharm ElSheikh -Egypt, 1209- 1211

[10] Saif - Eldin, M., Solaiman, A. and Aly, M. (1994): Prevalence and pathogenicity of enterobacteriaceae in rabbits. 2 nd Vet. Med. Cong. Zagazig pp: 94-100.

[11] Gueimonde M; Sánchez B, G de Los Reyes-Gavilán C, and Margolles A. (2013): Antibiotic resistance in probiotic bacteria. Front. 2013; 4: 202. Published online 2013 Jul18. doi: 10.3389/fmicb. 2013.00202 .

[12] Eiben Cs., Gippert T., Godor-Surmann K. and Kustos K (2008): Feed additives as they affect the fattening performance of rabbits. 9th World Rabbit Congress June 10-13, 2008 - Verona- Italy.

[13] Fortun-Lamothe and Boullier (2007): A review on the interactions between gut microflora and digestive mucosal immunity. Possible ways to improve the health of rabbits Reads DOI: 10.1016/j.livsci.2006.09.005

[14] Philip (2013): Alternatives to antibiotics as growth promoters for use in swine production: a review of Journal of Animal Science and Biotechnology $\mathbf{J}$ Anim Sci. Biotechnology. 4(1): 35

[15] Al-Baadani, HH, AM Abudabos, SI AlMufarrej, and M Alzawqari (2016): 'Effects of dietary inclusion of probiotics, prebiotics and synbiotics on intestinal histological changes in challenged broiler chickens', South African Journal of Animal Science, 46: 157-165.

[16] Swamy, Mallappa Kumara, Mohd Sayeed Akhtar, and Uma Rani Sinniah. (2016): 'Antimicrobial properties of plant essential oils against human pathogens and their mode of action: An updated review', Evidence-Based Complementary and Alternative Medicine, 2016.

[17] OIE. (2015): "Manual of Diagnostic Tests and Vaccines for Terrestrial Animals." In. Rome, Italy: OIE.

[18] NCCLS. (2007): "performance standards for Antimicrobial Susceptibility Testing; fifteenth Informational Supplement According to CLSI. CLSI document M100-s15." In CLSI, document M100s15., edited by National Committee for Clinical Laboratory standard. Clinical Laboratory standard Institue, Wayne.

[19] Sambrook, J.; Fritscgh, E.F.; and Mentiates (1989): Molecular cloning. A laboratory manual. Vol !., Cold spring Harbor Laboratory press, New York.

[20] Bisi-Johnson, M.A.; Obi, C.L.; Vasaikar, S.D.; Baba, K.A. and Hattori, T. (2011): Molecular basis of virulence in clinical isolates of Escherichia coli and Salmonella species from a tertiary hospital in the Eastern Cape, South Africa. Gut Pathogens 2011, 3:9. Published online 2011 Jun 10. doi: 10.1186/1757-4749-3-9.

[21] Ghanbarpour and Salehi (2010): Determination of Adhesin Encoding Genes in Escherichia coli Isolates from Omphalitis of Chicks. American Journal of Animal and Veterinary Sciences 5 (2): 91-96.

[22] Saad, S.E.; Hamed, O.M.; Awaad, M.H. and Haveez, E. (1974): The possible role in chicken in the epidemiology of E.coli infection in infant.Vet.Cairo. Univeristy.25.481-486.

[23] Brady, W. 1. (1968): measurements of some poultry performance parameters. Vet. Rec., 88:245-260.

[24] Snedecor, George W. and Cochran, William G. (1989): Statistical Methods, Eighth Edition, Iowa State University Press

[25] Duncan, D. B. (1955): Multiple range and multiple F tests. Biometrics11: 1-42.

[26] IBM Corp. Released (2011): IBM SPSS Statistics for Windows, Version 20.0. Armonk, NY: IBM Corp. 
[27] Licois, D., (2004): Domestic Rabbit Enteropathies. Proceeding of the 8 th Congress of World Veterinary Rabbit Association (WRSA), puebla, Mixico.711 Septamber 2004 pp.385-403.

[28] Prescott, J.F. (1978): Escherichia coli and diarrhea in the rabbit. Vet. Pathol. 15: 237-248. Proceedings - 8th World Rabbit Congress -September 7-10, 2004 - Puebla, Mexico

[29] Hassan, M.Moussa, Selim, M.A. and Abdeen, S.H. (2008): Pathological and bacteriological studies on diarrhea in newly born rabbits at sharkia province. SCVMJ, XIII (2) 417-435.

[30] Sabry A., Hassan and Mohamed W. Abd Al Azeem (2009): Determination of virulence gene markers Escherichia coli isolated from rabbit. Global veterinaria 3(3)260-267.

[31] Greenham,L.W. (1962): Some preliminary observations on rabbit mucoid enteritis. Vet. Rec. 79: 79-85.

[32] Sumitha and Sukumar (2014): described that an outbreak of Klebsiella pneumoniae associated with septicemia in rabbit farms. Int.J.Curr. Microbiol. App.Sci (2014) 3(11) 789-790.

[33] Martino P.A, and Luzi F. (2008): Bacterial Infections in Rabbit as Companion Animal: A Survey of Diagnostic Samples in Italy. Congress June 10-13, 2008- Verona - Italy Page1013-1014.9th World Rabbit.

[34] Karch H., Böhm H., Schmidt H., Gunzer F., Aleksic S., and Heesemann J. (1993): Clonal structure and pathogenicity of Shiga-like toxin-producing, sorbitolfermenting Escherichia coli O157:H-. J. Clin. Microbiol. 31:1200-1205.
[35] Nataro J. P. and Kaper J. B. (1998): Diarrheagenic Escherichia coli. Clin Microbiol Rev. Jan; 11(1): 142-201

[36] Swennes, Ellen M. Buckley, Carolyn M. Madden, Charles P. Byrd, Rachel S. Donocoff, Loretta Rodriguez, Nicola M. A. Parry, and James G. Fox (2013): Enteropathogenic Escherichia coli Prevalence in Laboratory Rabbits.Vet Microbiol. 2013 May 3; 163(3-4): 395-398.

[37] Kritas, S. K. and Morrison, R. B. (2005): Evaluation of probiotics as a substitute for antibiotics in a large pig nursery. Vet. Rec. 156: 447 - 448.

[38] Bovera f., nizza s., Marono s., Mallardo K., Piccolo G., tudisco r., de Martino 1., nizza a.(2010): Effect of mannan oligosaccharides on rabbit performance, digestibility and rectal Bacterial anaerobic populations during an episode of epizootic rabbit enteropathy. World Rabbit Sci., 18: 9 - 16 doi:10.4995/ wrs. 2010.18.02

[39] El Dimerdash, M.Z; Dalia, M.H.; Hanan, F.A. and Doaa, S.A.,(2011): Studies on the effect of some probiotics in Rabbits. SCVMJ, XVI (2) 151-168

[40] Mattar AF, Drongowski RA, Coran AG, and Harmon CM (2001): Effect of probiotics on enterocyte bacterial translocation in vitro. Pediatr Surg Int. May;17 (4):265-268.

[41] Panda, A.; McLeod, Tatarov, I.; Melton, A.; Kolappaswamy, K. H.; Petkov, D.; Coksaygan, T.; Livio, S.; C.; and Nataro, J. (2000): Escherichia coli O157:H7 Infection in Dutch Belted and New Zealand White Rabbits Comparative Medicine. (American Association for Laboratory Animal Science Volume 60, Number 1, p: 31-37). 


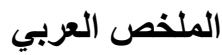

مدى انتثار المسببات البكتيرية المعوية والمتسببة لالتهابات المعوية في الأراتب ومحاولة السيطرة عليها باستخدام المضيفات العشبية

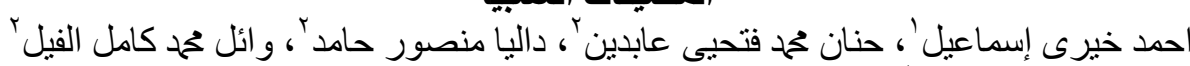

'الإدارة البيطرية - المستشفى البيطري بلئي بالحسينية

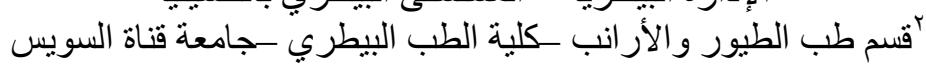

تم إجر اء مسح ميداني لرصد مدى انتشار بعض العدوى البكتيرية المعوية الحادة التي تجرم في تفتي التهابات الأمعاء المزمن

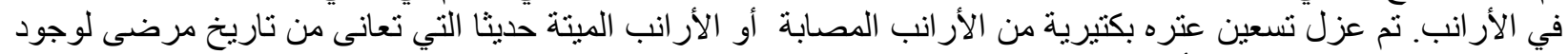

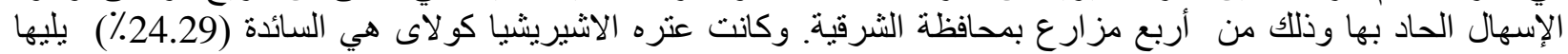

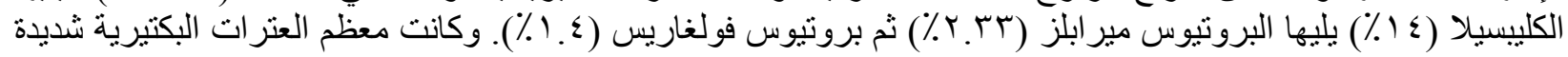

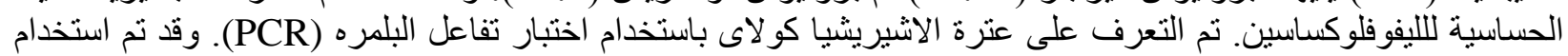

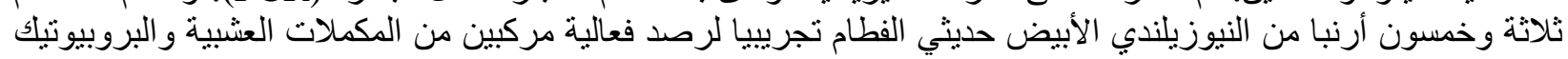

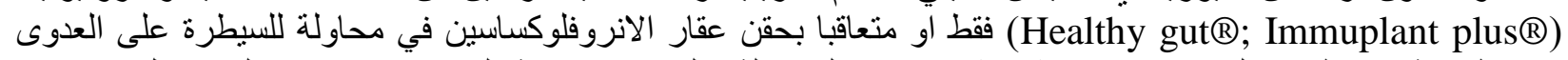

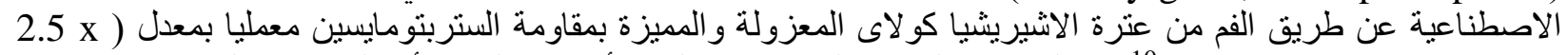

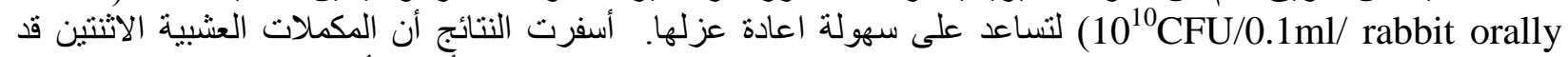

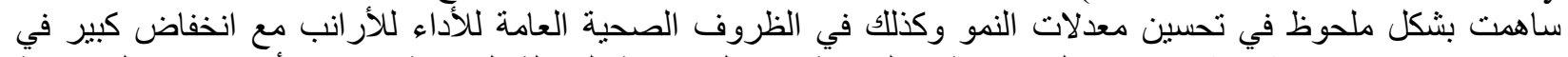

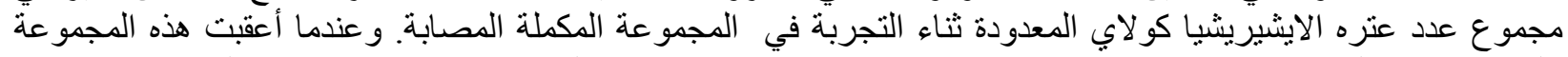

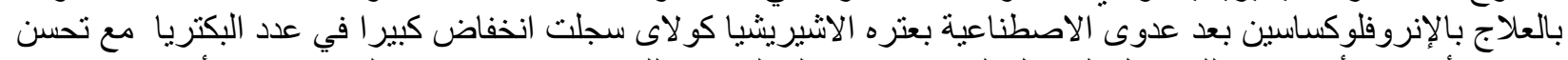

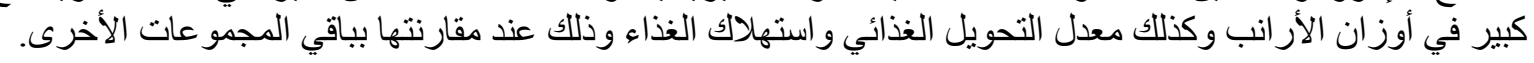

